\title{
Recreational swimming as a physical aspect of wellness and its impact on health tourism
}

\author{
Jovan Nićiforović ${ }^{1 *}$, Dalibor Stajić ${ }^{2}$ \\ ${ }^{1}$ University of Kragujevac, Faculty of Hotel Management and Tourism in Vrnjačka Banja, \\ Serbia \\ ${ }^{2}$ University of Kragujevac, Faculty of Medical Sciences, Kragujevac, Serbia
}

\begin{abstract}
Changes in Fitness indexvalues, monitored by the Urho Kaleva Kekkonen (UKK) Walking test, were examined in this study due to its practical application in the assessment of aerobic capacity, especially after planned wellness activities of moderate intensity. This research is designed as a quasi-experimental uncontrolled before and after study, and according to it, Fitness indexvalues obtained by the UKK test and body mass index (BMI) were evaluated before and after 8 weeks of planned wellness activities (recreational swimming). After the wellness activity, the average Fitness index value was increased by $1.13 \%$ (the difference was statistically significant with $\mathrm{p}=0.000$ ) while BMI value was significantly decreased by $1.82 \%(\mathrm{p}=0.000)$. Considering our results, the Fitness index could have practical importance for the assessment of endurance performance in man. That means that Fitness indexcan be used for es timating aerobic capacity and effect of wellne ss on health improvement and disease prevention.
\end{abstract}

Keywords: Walk Test, wellness, aerobic capacity

JEL classification: I11, I31

\section{Rekreativno plivanje kao fizički aspekt velnesa i njegov uticaj na zdravstveni turizam}

Sažetak: Promene vrednosti fitnesa indeksa, praćene Urho Kaleva Kekkonen (UKK) testom hodanja, is pitane su u ovoj studiji zbog njegove praktične primene u proceni aerobnog kapaciteta, posebno nakon planiranih velnes aktivnosti umerenog inteziteta. Ovo is traživanje je zamišljeno kao kvazi-eksperimentalno nekontrolis ano, i u skladu sa tim, vrednos ti Fitnes indeksa dobijene UKK testom i indeks a telesne mase (BMI) procenjene su pre i posle 8 nedelja planiranih velnes aktivnosti (rekreativno plivanje). Nakon velnes aktivnosti, prosečna vrednost Fitnes indeksa povećana je za 1,13\% (razlika je bila statistički značajna sa p= $0.000)$, dok je vrednost BMI značajno s manjena $1,82 \%(\mathrm{p}=0.000)$. Uzimajući u obzir naše rezultate, fitnes indeks bimogao imati praktični značaj za procenu performansi izdržljivosti kod čoveka. To značida bi se Fitnes indeks mogao koris titi za procenu aerobnog kapaciteta i uticaja velnesa na poboljšanje zdravlja i sprečavanje bolesti.

* jovan.niciforovic@kg.ac.rs

This article is an open access article distributed under the terms and conditions of the Creative Commons Attribution (CC BY) license (http://creativecommons.org/licenses/by/4.0/). 
Ključne reči: test hodanja, velnes, aerobni kapacitet JEL k lasifikacija: I11, I31

\section{Introduction}

The basic principle of wellness is a holistic, balanced approach to life and its defined by National Wellness Institute (NWI), as a process which helps people to make decisions and take steps towards success ful exis tence. The basic approach was a six-dimensional model developed by the co-founder of the NWI, Dr Bill Hettler (National Wellness Institute, 2021). One of these elements was the physicaldimension which is as sociated with an appropriate health care system, implementation of a healthy diet, the appropriate form of physical activity etc. (National Wellness Institute, 2021).

Social support, s pirituality, emotions are important, such as other factors, for creating more appropriate and individualized plans for improving health and wellness by multidimens ional influences each the other (Bezner, 2015; Stoewen, 2017). Visitors used their tourist experiences to achieve unique health and well-being benefits (Uysal et al., 2016). This is recognized by United Nations World Tourism Organization (2015) through strategic investment in tourismto generateincome by health-related services. Reasons for travel are relaxation, recreation, finding spiritual peace or on the other hand a specific medical service (Smith \& Puczkó, 2008). On the one hand, the behavior of tourists in their free time is influenced by the residual culture, and on the other hand, their behavior is influenced by the tourist culture, and this together represents the continuum of Leisure - Tourism. Both behaviors are influenced by personal motivation, personal characteristics, and physical environment (Carr, 2002). This relationship can be significant for the behavior of tourists who have opted for services in health touris m.

Physicalinactivity, more than smoking, leads to disease and premature mortality, causing Sedentary Death Syndrome (SeDS) (Vanhees et al., 2012; Wen et al., 2011; Young et al., 2016). It is caused by developed technology in all spheres of life but on the other hand, interest in healthy lifestyles is growing (Gibbs et al., 2015; Rezende et al., 2016; Thivel et al., 2018; Tremblay et al., 2017).

Chronic diseases such as diabetes, hypertension, various types of cancer are the most common causes of death in recent decades. Therefore, within health care, it is necessary to conduct education on healthy lifes tyles and give appropriate advice, especially to the elderly (Devereux-Fitzgerald et al., 2016; Mendis, 2017; Tsay et al., 2017; World Health Organization, 2016).

Contraction of es pecially skeletal muscles affects the increase in energy consumption and in other words represents physical activity. It is very important because it makes bones and muscles stronger, increases self-confidence and affects better control of all parameters important for improving vitality and health (Cas persen et al., 1985; Cristina \& Catalin, 2015; Hans on \& Jones, 2015). Planned, structured and repetitive physical activity is known as exercise (Cas persen et al., 1985).

Moderate-intensity physical activity lasting at least 150 minutes per week or vigorous intensity activity lasting at least 75 minutes per week or a suitable combination of these activities is very important for improving health of the adults (Buchner, 2014).

Direct and indirect tests are methods used for estimating cardiovascular fitness.

The aim of this paper was to evaluate the changes in Fitness indexvalues es timated by UKK Walk Test, its relationship with body mass index (BMI), and its practical application in aerobic capacity estimation, es pecially after planned moderate wellness activities such as 
recreational swimming. All this has an impact on health tourism development (Smith \& Puczkó, 2008).

\section{Materials and methods}

Thirty healthy men aged 20-65 (mean $36 \pm 0.59$ ) without any wellness activities or habits volunteered to participate in this study. Res pondents were randomly selected, contacted by telephone and if they met the criteria from guide for the UKK test (Oja et al., 2013), they were included in the study. The participants with: osteomuscular, neurological and cardiovascular dis orders; any recent injuries of the foot, knee, or leg were excluded. This is a limitation of this study, which is why it cannot cover theentire population. All respondents have given their informed consent for participation in the res earch study. Objectives with all details of the applied procedures of this study were explained to all subjects. This research is designed as a quasi-experimental research uncontrolled before and after study. All procedures were performed in accordance with the ethical standards of the local Ethics Committee and the Hels inkiDeclaration. According to the design of the study, the Fitness index values obtained by the UKK test were evaluated before wellness activities (recreational swimming.) and after 8 weeks of planned wellness activities. All procedures of our examination were conducted in accordance with current epidemiological recommendations.

Within 48 hours before the test all participants were instructed: not to perform any hard physical activity, to avoid the use of cigarettes, alcoholic drinks, caffeinated beverages and heavy meal 2-3 hours before testing. All subjects were given instruction to be dressed appropriately for the examination and microclimatic conditions for all participants were the s ame (room temperature at $21.7 \pm 1.5^{\circ} \mathrm{C}$, humidity at $42.5 \pm 5.4 \%$ ).

\subsection{Recreational swimming}

Many people decide to start their fitnes s program with swimming. This is very important because most skeletal muscles are activated during swimming and thus improve cardiovascular capacity (Dishman \& Washburn, 2004; Le Mura \& Von Duvillard, 2004; Nieman, 2003). For 8 weeks, 3 days/week and $50 \mathrm{~min} /$ days training programwas performed by all participants. Conditions were consistent for all subjects. Before and after the planned wellnes s activities, a UKK walking test was performed.

\subsection{UKK test}

The UKK Walk Test is Indirect test (method used to derive a Fitness index values) that provides a simple and inexpensive way to assess aerobic fitness. Character and type of aerobic activity was determinated by Fitness index level (Laukkanen et al., 2000; Oja et al., 2013; Zakariás et al., 2003).

The Urho Kaleva Kekkonen Institute (UKK Institute) has developed the most important UKK Walking Test to as sess aerobic capacity for anyone between the ages of 20 and 65 without having any disability or illnes s for which brisk walking is contraindicated. People who are overweight can use the test but not those who are in top form. Various factors can affect the validity of the test. Rough terrain, inaccurate measurement of heart rate, time and distance are some of thesefactors. Inadequate equipment, too slow walking, and medications used to treatheart problems can also affect results. The UKK Walk Test is important because it determines the maximum aerobic power (VO2 max), the gold standard for assessing 
cardiovascular condition, as well as the functionality of the mu sculoskeletal system, which is why the test is applicable to the general population (Oja et al., 2013).

The gains of performing UKK test on a treadmill are: the ability of precise determination of distance $(2 \mathrm{~km})$, monitoring heart rate during the test and constant monitoring subjects by trained personnel (Laukkanen et al., 2000; Oja et al., 2013).

Pulse monitor (Polar 610i), appropriate software, stopwatch, treadmill and environmental meas uring device (KIMOHD200), are the necessary equipment used to as ses s the required parameters in the study.

The procedure is performed under the supervision of trained staff before and after wellness activities (recreationals wimming). The software automatically calculates several parameters. Among them is fitness index important for representing endurance performance of participants. The Fitness class according to the fitness index (Oja et al., 2013) is:

Fitness index Fitness class

$<70 \quad$ Considerably below average

$70-89 \quad$ Somewhat below average

90-110 Average

$111-130 \quad$ Somewhat above average

$>130 \quad$ Considerably above average

The BMI is obtained from the height and weight of the respondents. The BMI can also be calculated froman equation $\left(\mathrm{kg} / \mathrm{m}^{2}\right)$ (Douketis et al., 2005). For most adults, an ideal BMI is in the 18.5 to 24.9 range. If BMI is (Douketis et al., 2005):

- below 18.5 - underweight range,

- between 18.5 and 24.9 - normal (healthy) weight range,

- between 25 and 29.9 - overweight range,

- between 30 and 39.9 - obese range.

\subsection{Statis tical analysis}

In this study, the results were presented as arithmetic mean and standard deviation (SD) and for data analysis IBM SPSS Statistics 20.0 was used. For checking the normality of the data distribution we used the Shapiro-Wilk test. Simple linear regression analyses and bivariate correlation were als o performed to show relationships between the BMI and Fitness index values estimated by UKK test. The difference between the values of Fitness index and BMI before and after the 8-week wellnes s activity was determined using the paired-samples t-test or nonparametric Wilcoxon signed-rank test for variables that did not follow the normal distribution. The results were considered statistically significant if the value of $\mathrm{p}$ was less than 0.05 .

\section{Results}

Simple linear regression was performed to show relationships between the BMI and Fitness index values estimated by UKK test $\left(\mathrm{R}^{2}=0.651\right.$, $\left.\mathrm{y}=40.43-0.15 \mathrm{x}\right)$ (Figure 1). For participants before wellnes s activities (recreational s wimming), the Fitness indexmean value with standard deviation was $(70.9 \pm 9.36)$, mean value of BMI was $(29.8 \pm 2.58)$ and correlation analyses revealed strong negative correlation between these parameters (Spirman $\mathrm{r}=-0.807, \mathrm{p}<0.001)$ (Figure 1). 
Figure 1: Simple linear regression analyses between the Fitness index values predicted by UKK test and BMI for participants before Wellness activities

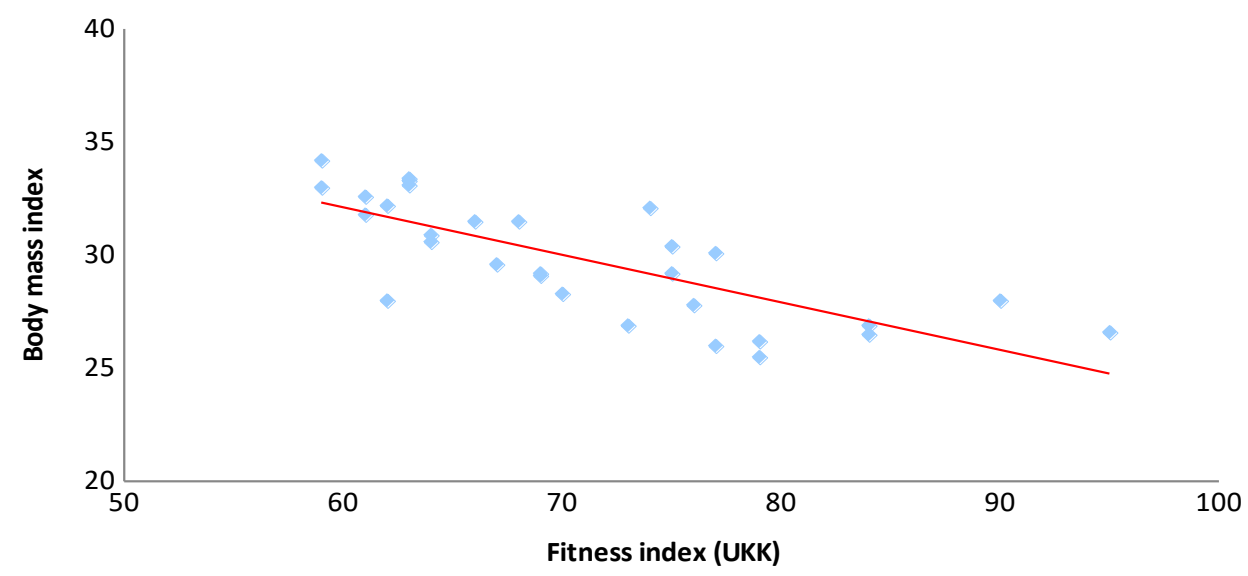

Source: Author's research

After the recreational swimming according to the design of the study, Fitness index mean value was $(71.7 \pm 9.45)$, mean value of BMI was $(29.27 \pm 2.48)$ and strong negative correlation was confirmed (Pearson's $r=-0.739, \mathrm{p}<0.001$ ) (Figure 2). Simple linear regression was performed too $\left(\mathrm{R}^{2}=0.546, \mathrm{y}=42.17-0.18 \mathrm{x}\right)$ (Figure 2$)$.

Figure 2: Simple linear regression analyses between the Fitness index values predicted by UKK test and BMI for participants after Wellness activities

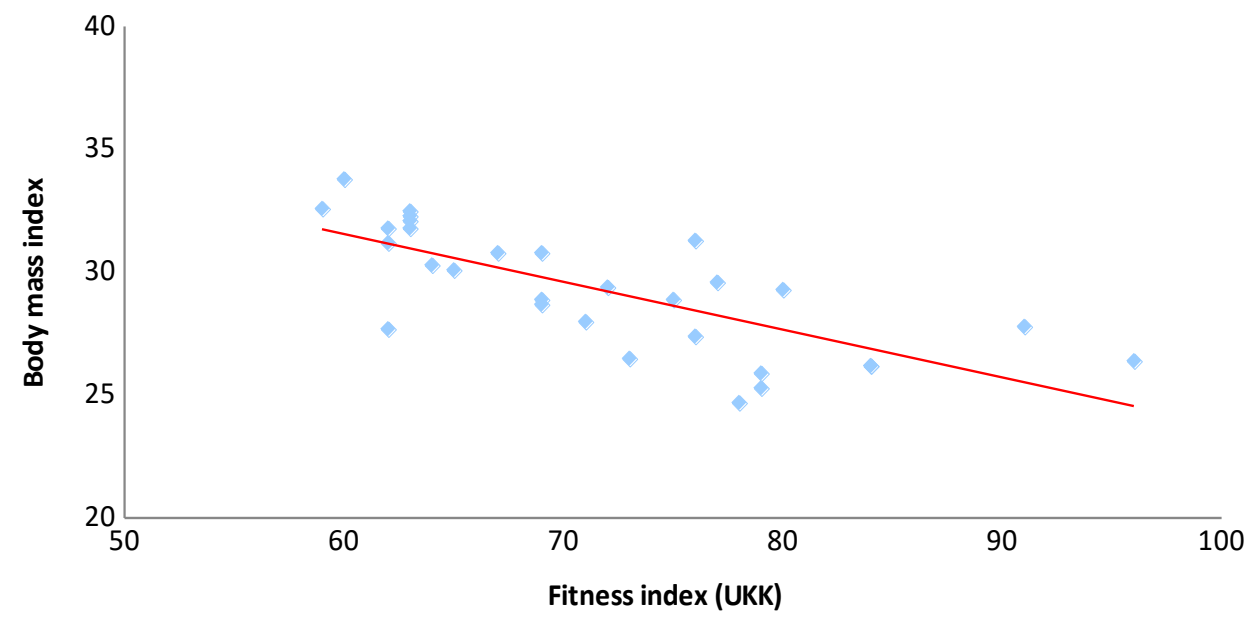

Source: Author's research

When comparing the values obtained before and after the recreational swimming, the average Fitness index value was increased by 0.8 or $1.13 \%$ and the average BMI was decreased by 0.54 or $1.82 \%$. The difference between Fitness indexes timated before and after 8 -week activity was statistically significant (Wilcoxon signed-rank test gave $\mathrm{p}=0.000$ ). 
Nićiforović, J., Stajić, D. - Recreational swimming as a physical aspect of wellness and its impact on health tourism - Hotel and Tourism Management, 2021, Vol. 9, No. 1: 135-144.

After wellness activity, the decrease of BMI was also statis tically significant (paired-samples t-test $\mathrm{p}=0.000$ ).

Thes e results indicate an improvement in the aerobic capacity of the participants, represented by an increase in Fitness index and a decrease in BMI, which is important for improving health.

\section{Dis cussion}

Physical activity such as recreational swimming causes certain positive effects on body composition and weight, by losing body fat (Mestek et al., 2008), decreas ing blood pressure, lowering of heart rate, increasing flexibility, improving socialization and decreasing depression (McArthur \& Raedeke, 2009). The metabolic riscs factors were reduced, while endurance performance was increased by physical activity (Taliaferro et al., 2008). This affects the improvement of vitality and normal development, and it is important to say that it is also affected by other conditions such as air, water and healthy food (Bjelajac et al., 2021).We can recommended duration, inesity and frequency of recreational swimming by using Fitness index estimated by UKK W alk Test (Laukkanen et al., 2000).

Decreasing of BMI mean value approximately $1.82 \%$ was in agreement with results in study of Zahedmanesh et al. (2013), after 8 weeks wellness activities. The BMI values from our study were inversely correlated with fitness level, which is consistent with other studies (Brunet et al., 2007; Ortega et al., 2007; Parmar \& Vaghela, 2015). Our research indicates that predicting physical fitness depends on physical activity performance as an important factor.

We also found $1.13 \%$ increasing in endurance performance after 8 weeks of an aerobic exercise program followed by subjects which is consistent with Sözen and Akyıldız (2018) study, who found $4 \%$ increase after an aerobic exercise programfor the s ame time (8 weeks). Very similar results have been achieved in study of Overend et al. (1992) who reported that ten weeks of performing low and high intensity exercises had been benefitial for subjects. The study by Short et al. (2004) found that four months of aerobic exercise program is needed for $9 \%$ increasing in aerobic capabilities of the respondents. That leads to dis ease prevention and health improvement. It is a way to achieve individual and overall well-being and affects the promotion of health tourism whose part wellness is (Marmion \& Hindley, 2019).

On the other hand results of Crowley et al. (2017) indicates that for a positive transition to swimming performance, the relationship between high speed and force, low volume and specific resistance training programs are important (Crowley et al., 2017).

Tertiary activities such as health, education, administration, networking etc. have significant role as new settings for physical activity promotion, because these worksites had the sedentary time effect on health. Moderate physical activity has a significant role in the elimination of this effect (Coradin et al., 1998; Ekelund et al., 2016).

Considering previous results, changing life habits (especially the bad ones) and adopting healthy lifestyles is of crucial importance for health benefits. This leads to the implementation of wellness activities, and the critical attitude of service users which is us eful for improving the quality of services. This affects the decision-making about the choice, type and quality of services, which results in the improvement of health touris $m$ in all as pects.

According to Fitness index values obtained during dynamic UKK test, we have an opinion that these results are giving a practical importance to Fitness index for the as sess ment of aerobic abilities in man. High Pears on's correlation coefficient indicates inverse dependence 
between BMI and Fitness index. That means that Fitness Index can be used for estimating aerobic capacity.

In his study, Carr (2002) concluded that the behavior of people during their free time and their behavior as tourists should not be considered separately because, despite the potential differences, there are certain common influences that determine their behavior. So, those who are engaged in recreational s wimming, in their free time, will most likely practice this habit at the destination they have chosen as part of their tourist trip.

This is very important for the physical aspect of wellness, which is an integral part of health touris m, and has a significant impact on its development and its promotion.

\section{Conclusion}

Considering results and limitation of this study, all that indicates that the Fitness Index could be used for as sessment endurance performance obtained during moderate-intens ity wellnes s activities. Our examination could be a basis for new more comprehensive research on a given topic. All this is important because it leads to the improvement of health, disease prevention, achieving individual and universal well-being and affects the promotion of health touris $m$ and wellness, as its integral part.

\section{Conflict of interest}

The authors declare no conflicts of interest.

\section{References}

1. Bezner, J. R. (2015). Promoting health and wellness: implications for physical therapist practice. Physical Therapy, 95, 1433-1444. https://doi.org/10.2522/ptj.20140271.

2. Bjelajac, Ž., Filipović, A., \& Banović, B. (2021). Instruments of support in promotion of healthy food and food safety culture. Economics of Agriculture, 68(1), 241-255. https://doi.org/10.5937/ekoPolj2101241B

3. Brunet, M., Chaput, J. P., \& Tremblay, A. (2007). The as sociation between low physical fitness and high body mass index or waist circumference is increasing with age in children: The 'Quebec en Forme' project. International Journal of Obesity, 31(4), 637643. https://doi.org/10.1038/sj.ijo.0803448

4. Buchner, D. M. (2014). The Development and content of the 2008 physical activity guidelines for Americans. Journal of Physical Education, Recreation \& Dance (JOPERD), 85(7), 13-16. https://doi.org/10.1080/07303084.2014.937176

5. Carr, N. (2002). The tourism-leisure behavioural continuum. Annals of Tourism Research, 29(4), 972-986. https ://doi.org/10.1016/S0160-7383(02)00002-6

6. Cas persen, C. J., Powell, K. E., \& Christenson, G. M. (1985). Physical activity, exercise, and physical fitness: Definitions and distinctions for health-related research. Public Health Reports, 100, 126-131.

7. Coradin, L., Gothshall, R. W., Eatan, S. B., \& Eatan, S. B. III. (1998). Physical activity, energy expenditure and fitness: An evolutionary perspective. International Journal of Sports Medicine, 19, 328-335. https ://doi.org/10.1055/s-2007971926

10. Cristina, M. M., \& Catalin, G. A. (2015). Study on the influence of training at altitude $(2000 \mathrm{~m})$ on the maximum aerobic velocity in athletics (Mountain race). Science, Movement and Health, 15(2), 135-146. 
11. Crowley, E., Harris on, J. A., \& Lyons, M. (2017). The impact of res istance training on swimming performance: A systematic review. Sports Medicine, 47(11), 2285-2307. https://doi.org/10.1007/s40279-017-0730-2

12. Devereux-Fitzgerald, A., Powell, R., Dewhurst, A., \& French, D. P. (2016). The acceptability of physical activity interventions to older adults: A systematic review and meta-synthesis. Social Science \& Medicine, 158, 14-23. https://doi.org/10.1016/j.socscimed.2016.04.006

13. Dishman, K., \& Washburn, A. (2004). PhysicalActivity Epidemiology. Champaign: HK.

14. Douketis, J. D., Paradis, G., Keller, H., \& Martineau, C. (2005). Canadian guidelines for body weight classification in adults: Application in clinical practice to screen for overweight and obesity and to assess disease risk. Canadian Medical Association Journal (CMAJ), 172(8), 995-998. https://doi.org/10.1503/cmaj.045170

15. Ekelund, U., Steene-Johannessen, J., Brown, W. J., Fagerland, M. W., Owen, N., Powell, K. E., ... Lee, I. M. (2016). Does physical activity attenuate, or even eliminate, the detrimental as sociation of sitting time with mortality? A harmonised meta-analys is of data from more than 1 million men and women. Lancet, 388, 1302-1310. https ://doi.org/10.1016/S0140-6736(16)30370-1

16. Gibbs, B. B., Hergenroeder, A. L., Katzmarzyk, P. T., Lee, I. M., \& Jakicic, J. M. (2015). Definition, measurement, and health risks as sociated with sedentary behavior. Medicine and Science in Sports and Exercise, 47, 1295-1300. https://doi.org/10.1249/ms s.0000000000000517

17. Hanson, S., \& Jones, A. (2015). Is there evidence that walking groups have health benefits? A systematic review and meta-analys is. British Journal of Sports Medicine, 49(11), 710-715. https://doi.org/10.1136/bjsports -2014-094157

18. Laukkanen, R., Kukkonen-Harjula, K., Oja, P., Rasanen, M., \& Vuori, I. (2000). Prediction of change in maximal aerobic power by the 2-km Walk Test after walking training in middle-aged adults. International Journal of Sports Medicine, 21(2), 113116. https://doi.org/10.1055/s-2000-8872

19. Le Mura, L. M., \& Von Duvillard, S. P. (2004). Clinical exercise physiology. Philadelphia: LWW.

20. Marmion, M., \& Hindley, A. (2019). Tourism and health: Understanding the relationship. Good Health and Well-Being, 1-9. https://doi.org/10.1007/978-3-31969627-0_16-1

21. McArthur, L. H., \& Raedeke, T. D. (2009). Race and sex in college students physical activity correlates. American Journal of Health Behavior, 33, 80-90. https://doi.org/10.5993/AJHB.33.1.8

22. Mendis, S. (2017). Global progress in prevention of cardiovascular disease. Cardiovascular Diagnosis and Therapy, 7(1), 32-38. https ://doi.org/10.21037/cdt.2017.03.06

23. Mestek, M. L, Paisance, E., \& Grandjean, P. (2008). The relationship between pedometer-determined and self-reported physical activity and body composition variables in college-aged men and women. Journal of American College Health, 57, 3944. https://doi.org/10.3200/JACH.57.1.39-44

24. National Wellness Institute. (2021). The six dimensions of wellness. Retrieved March 12, 2021 from https://nationalwellnes s.org/resources/six-dimensions-of-wellness/

25. Nieman, D. C. (2003). Exercise testing and prescription. New York: MHHE.

26. Oja, P., Mänttäri, A., Pokki, T., Kukkonen-Harjula, K., Laukkanen, R., Malmberg, J., ... Suni, J. (2013). UKK WALK TEST Tester's guide. Tampere: UKK Institute for Health Promotion Res earch.

27. Ortega, F. B., Tresaco, B., Ruiz J. R., Moreno L. A., Martin-Matillas, M., Mesa J. L., ... Castillo, M. J. (2007). Cardiorespiratory fitness and sedentary activities are as sociated 
with adiposity in adolescents. Obesity, 15(6), 1589-1599. https://doi.org/10.1038/oby.2007.188

28. Overend, T. J., Paters on, D. H., \& Cunningham, D. A. (1992). The effects of interval and continuous training on the aerobic parameters. Canadian Journal of Sport Science, 17(2), 129-134.

29. Parmar, D., \& Vaghela V. (2015). Study of physical fitness index using modified Harvard Step Test in relation with body mass index in physiotherapy students. International Journal of Recent Advances in Multidisciplinary Research, 2(12), 10751077.

30. Rezende, L. F., Sa, T. H., Mielke, G. I., Viscondi, J. Y., Rey-Lopez, J. P., \& Garcia, L. M. (2016). Allcausemortality attributable to sitting time: Analysis of 54 countries worldwide. American Journal of Preventive Medicine, 51, 253-263. https://doi.org/10.1016/j.amepre.2016.01.022

31. Short, K. R., Vittone, J. L., Bigelow, M. L., Proctor, D. N., \& Nair, K. S. (2004). Age and aerobic exercise training effects on whole body and mucle protein metabolism. American Journal of Physiology-Endocrinology and Metabolism, 286(1), 92-101. https://doi.org/10.1152/ajpendo.00366.2003

32. Smith, M., \& Puczkó, L. (2008). Health and wellness tourism. Oxford: Routledge.

33. Sözen, H., \& Akyıldı, C. (2018). The effects of aerobic and anaerobic training on aerobic and anaerobic capacity. The Joumal of International Anatolia Sport Science, 3(3), 331-337. https://dx.doi.org/10.5505/jias science.2018.29392

34. Stoewen, D. L. (2017). Dimensions of wellness: Change your habits, change your life. The Canadian Veterinary Journal, 58(8), 861-862.

35. Taliaferro, L. A., Rienzo, B. A., Pigg, R., Miller, M. D., \& Dodd, V. J. (2009). As sociation between physical activity and reduced rates of hopelessness, depression, and suicidal behavior among college students. Journal of American College Health, 57(4), 427-36. https://doi.org/10.3200/jach.57.4.427-436

36. Thivel, D., Tremblay, A., Genin, P. M., Panahi, S., Rivière, D., \& Duclos, M. (2018). Physical activity, inactivity, and sedentary behaviors: Definitions and implications in occupational health. Front Public Health, 6, 1-5. https://doi.org/10.3389/fpubh.2018.00288

37. Tremblay, M. S., Aubert, S., Barnes, J. D., Saunders, T. J., Carson, V., Latimer-Cheung, A. E., ... Chinapaw M. J. M. (2017). Sedentary behavior research network (SBRN) Terminology consensus project process and outcome. International Journal of Behavioral Nutrition and Physical Activity, 14(1), 75. https ://doi.org/10.1186/s 12966017-0525-8

38. Tsay, S. L., Ko, W. S., \& Lin, K. P. (2017). The lifestyle change experiences of cancer survivors. Journal of Nursing Research, 25(5), 328-335. https://doi.org/10.1097/jnr.0000000000000178

39. United Nations World Tourism Organization (UNWTO) (2015). Tourism and the sustainable development goals. Madrid: UNWTO.

40. Uysal, M., Sirgy, M. J., Woo, E., \& Kim, H. (2016). The impact of tourists activities on tourists' subjective wellbeing. In M. Smith \& L. Puczkó (Eds.), The Routledge Handbook of Health Tourism (pp. 65-78). Abingdon: Routledge.

41. Vanhees, L., Geladas, N., Hansen, D., Kouidi, E., Niebauer, J., Reiner, Z., ... Vanuzzo, D. (2012). Importance of characteris tics and modalities of phy sical activity and exercise in the management of cardiovascular health in individuals with cardiovascu lar risk factors: recommendations from the EACPR (Part II). European Journal of Preventive Cardiology, 19(5), 1005-1033. https://doi.org/10.1177/1741826711430926

42. Wen, C. P., Wai, J. P., Tsai, M. K., Yang, Y. C., Cheng, T. Y., Lee, M. C., ... Wu X. (2011). Minimum amount of physical activity for reduced mortality and extended life 
expectancy: A prospective cohort study. Lancet, 378(9798), 1244-1253. https ://doi.org/10.1016/S0140-6736(11)60749-6

43. W orld Health Organization. (2016). Global health estimates 2016: Deaths by cause, age, sex, by country and by region, 2000-2016. Retrieved March 12, 2021 from https://www.who.int/healthinfo/global_burden_disease/estimates/en/index1.html

44. Young, D. R., Hivert, M. F., Alhassan, S., Camhi, S. M., Fergu son, J. F., Katzmarzyk, P. T., ... Yong, C. M. (2016). Sedentary behavior and cardiovascular morbidity and mortality: A science advisory from the American Heart Association. Circulation, 134, 262-279. https://doi.org/10.1161/CIR.0000000000000440

45. Zahedmanesh, F., Zafari A., \& Zahedmanesh F. (2013). The effects of swimming combined training on body composition in academic level athletes women. European Journal of Experimental Biology, 3(1), 228-231.

46. Zakariás, G., Petrekanits, M., \& Laukkanen, R. (2003). Validity of a 2-km Walk Test in predicting the maximal oxygen uptake in moderately active Hungarian men. European Journal of Sport Science, 3(1), 1-8. https://doi.org/10.1080/17461390300073104 